Jurnal Ekonomi, Bisnis, dan Akuntansi (JEBA) Volume 21 Nomor 02 Tahun 2019

\title{
KAJIAN KARAKTERISTIK KEWIRAUSAHAAN TERHADAP KEBERHASILAN USAHA UKM (STUDI KASUS SENTRA INDUSTRI KONVEKSI DUSUN MLANGI DAN SAWAHAN NOGOTIRTO GAMPING SLEMAN YOGYAKARTA)
}

\author{
Maisaroh* \\ Prodi D3 Manajemen Perusahaan Fakultas Ekonomi Universitas Islam Indonesia \\ *Email corresponding author :maisaroh@uii.ac.id
}

\begin{abstract}
Abstrak
Penelitian ini merupakan penelitian kualitatif, yang mencoba mengkaji karakteristik kewirausahaan dikaitkan dengan keberhasilan usaha UMKM di dusun Sawahan dan Mlangi Nogotirto Gamping Sleman Yogyakarta. Tujuan penelitian adalah untuk mengidentifikasi profil UMKM, menganalisis karakteristik kewirausahaan yang dimiliki, serta menganalisis persepsi tentang keberhasilan usaha UMKM di dusun Sawahan dan Mlangi. Dengan menggunakan 6 (enam) indikator karakteristik kewirausahaan (percaya diri, keberanian mengambil resiko, kepemimpinan, inovasi, motivasi usaha, serta kegigihan dalam menjalankan usaha, peneliti mengumpulkan data melalui penyebaran kuesioner dan wawancara mendalam terhadap 6 (enam) responden pelaku UMKM. Hasil penelitian membuktikan bahwa, secara umum profil usaha di dusun Sawahan dan Mlangi masih di dominasi oleh usaha konveksi, dengan skala usaha kecil dan menengah. Penyerapan tenaga kerja mencapai 7 - 25 orang tenaga kerja per UMKM, dan omset per bulan rata-rata 40 - 100 kodi. Terkait dengan karakteristik kewirausahaan, dari 6 (enam) indikator yang dianalisis, hanya indikator karakteristik inovasi yang belum dimiliki oleh pelaku usaha di dusun ini, sementara 5 (lima) karakter lainnya, sudah terbangun dan melekat dalam budaya kerja mereka sehari hari. Karakter tersebut adalah karakter percaya diri, keberanian mengambil resiko, kepemimpinan, motivasi usaha, serta kegigihan dalam menjalankan usaha. Yang menarik, dari hasil wawancara mendalam juga terungkap peran tingkat relegiusitas yang dimiliki pelaku usaha dalam kehidupan sehari-hari, dan memberikan pengaruh dalam keberhasilan usaha. Dalam penelitian ini juga diidentifikasikan persepsi pelaku usaha terhadap keberhasilan usaha. Dan hasilnya hampir seluruh responden yang ditanya menjawab, bahwa bagi mereka keberhasilan usaha itu terkait dengan 3 ( tiga) hal, pertama usaha yang terus berjalan, anak-anak yang bisa sekolah dan mengaji, dan bahagia menjalankan usaha tersebut.
\end{abstract}

Kata kunci : kewirausahaan, karakter kewirausahaan, UMKM, keberhasilan bisnis

\begin{abstract}
This is a qualitative research, which try to study the entrepreneurial characteristics associated with the success of SME's on convection center industry at Sawahan and Mlangi Nogotirto Gamping Sleman Yogyakarta.The purpose of this research is to identify the profile of $S M E$ 's, to analyze the entreprenuership character of entrepreneur, and to analyze perception about the success of SME's on convection center industry at Sawahan and Mlangi. Using 6 (six) indicators of entrepreneurial character (confidence, risk-taking, leadership, innovation, business motivation, and persistence in conducting business), researchers collected data through questionnaires and in-depth interviews of 6 (six) SME's respondents connected to data related.The results shown that, in general, business profile on convection center industry at Sawahan and Mlangi is still dominated by convection businesses, with small and medium scale businesses. Labor absorption reaches 7 - 25 workers per SME's, and the average sales is 40 100 kodi per month. On the other hand, related to the character of entrepreneurship, from 6 (six) indicators analyzed, SME's are not have innovation character yet, but 5 (five) other characters, have been built and embedded in their daily work culture. Those characters are
\end{abstract}


confident, take a risks, leadership, business motivation, and persistence in running a business. Interestingly, the results of in-depth interviews also revealed the role of the relegiusity level in everyday life, and give effect to the success of the business. In this study also identified perceptions of business actors on business success. And the results shown that all respondents answered, that according to them, the success of the business is related to 3 (three) things, the first business that is running continuesly, their children who can study and study, and happy to run the business.

Key words : entreprenuership, entrepreurship characters, SME's, Success business

\section{PENDAHULUAN}

Semakin pesatnya perkembangan UMKM di bidang industri konveksi baik di wilayah Yogyakarta dan Jawa Tengah, tentu saja berdampak pada tingkat persaingan yang ketat di pasar konveksi. Oleh karena itu setiap UMKM harus memiliki kinerja yang unggul untuk bisa berkembang dan bertahan di pasar industri. Tidak terkecuali UMKM sentra industri dusun Mlangi, untuk dapat memenangkan persaingan, harus meningkatkan kualitas manajemen dan operasionalnya secara lebih baik. Kinerja yang unggul biasanya akan berdampak pada keberhasilan usaha dari UMKM yang bersangkutan. Keberhasilan usaha tentu saja diukur berdasarkan kelangsungan hidup, laba, laba atas investasi, pertumbuhan penjualan, jumlah pekerja, kebahagiaan, reputasi, dan sebagainya (Islam, Keawchana dan Yusuf, 2011).

Karakteristik wirausaha yang dimiliki oleh pribadi pemilik UMKM merupakan salah satu faktor yang berpengaruh dalam keberhasilan usaha yang dilakukan. Ciri khas UMKM yang membedakan dengan usaha lainnya akan ditentukan oleh karakteristik pribadi seorang wirausaha. Berdasarkan pengertian wirausaha, yang didefinisikan sebagai suatu kemampuan (ability) dalam berpikir kreatif dan berperilaku inovatif yang dijadikan dasar, sumber daya, penggerak tujuan, siasat kiat dan proses dalam menghadapi tantangan hidup (widodo, 2011), maka seorang wirausaha harus memiliki karakter kreatif, inovatif dalam mengelola sumber daya dan peluang yang dimiliki, serta berani mengambil resiko untuk melaksanakan tujuan, strategi/siasat yang sudah direncanakan untuk menghadapi tantangan persaingan bisnis. . Seorang yang kreatif inovatif, tidak akan kehabisan ide untuk mengembangkan bisnisnya. Sehingga ketika di pasar produk yang ditawarkan sudah mulai jenuh, maka bisa membuat atau mengembangkan produk yang baru untuk ditawarkan kembali. Pembaharuan produk, dan proses sebagai hasil kreatif akan mengurangi tingkat kejenuhan pasar akan produk kita, bahkan akan semakin membuat konsumen menjadi loyal dengan produk kita. Selain karakteristik di atas, proses kepemimpinan, motivasi/semangat berprestasi, rasa percaya diri, dan karakteristik pribadi lainnya juga menjadi salah satu karakteristik yang dominan dalam diri seorang wirausaha.

Secara geografis, dusun Mlangi dan Sawahan ini berdekatan, sedang secara sosial, sebagian besar penduduknya berasal dari satu trah keturunan yaitu keturunan Kyai Nuriman. Sebagai sentra industri konveksi, maka ada banyak UKM di dusun Mlangi, yang setiap hari memproduksi produk pakaian jadi dengan pangsa pasar adalah para pelancong yang berwisata di Yogyakarta dan sebagian Jawa Tengah. Operasional UMKM sehari-hari dijalankan dengan konsep tradisional, di kelola secara individu (keluarga), dan manajemen yang sangat sederhana, meskipun beberapa UMKM dengan skala menengah sudah mencapai omset dalam skala milyar per tahun. Diyakini pelaku usaha di Dusun Sawahan dan Mlangi 
memiliki karakter yang kuat dalam berwirausaha, yang menjadi salah satu faktor keberhasilan usaha.

Beberapa penelitian terdahulu terkait menyebutkan bahwa karakteristik kewirausahaan memiliki peran dalan keberhasilan usaha UMKM. Indiarti dan Langenberg (2004), melakukan penelitian mengenai perkembangan usaha UKM menyebutkan bahwa faktor-faktor yang mempengaruhi perkembangan usaha tradisional adalah modal psikologis entrepreneur, manajemen sumber daya manusia, inovasi, karakteristik dari entrepreneur, dan karakteristik usaha itu sendiri. Chamduang, Daowieng, dan Jorajit (2011) dalam penelitian yang mereka lakukan pada usaha kecil di Songkhla, menyatakan bahwa karakteristik kewirausahaan ditentukan oleh kreatifitas, percaya diri, percaya dengan keberuntungan, membangun jaringan hubungan, memiliki pengetahuan usaha dan usaha yang efektif untuk mencapai keberhasilan usaha. Islam, Khan dan Obaidullah (2011), melakukan penelitian di Bangladesh, dan hasil penelitiannya menunjukkan bahwa faktor karakteristik kewirausahaan dan karakteristik perusahaan mempengaruhi keberhasilan UMKM di Bangladesh.

Tujuan penelitian adalah untuk mengidentifikasi profil UMKM, menganalisis karakteristik kewirausahaan yang dimiliki, serta menganalisis persepsi tentang keberhasilan usaha UMKM di dusun Sawahan dan Mlangi. Dengan menggunakan 6 (enam) indikator karakteristik kewirausahaan (percaya diri, keberanian mengambil resiko, kepemimpinan, inovasi, motivasi usaha, serta kegigihan dalam menjalankan usaha, peneliti mengumpulkan data melalui penyebaran kuesioner dan wawancara mendalam terhadap 6 (enam) responden pelaku UMKM. Hasil dari penelitian ini diharapkan dapat memberikan gambaran tentang profil kelompok usaha konveksi di Dusun Sawahan Mlangi, serta mengidentifikasi karakter kewirausahaan yang dimiliki dan menjadi faktor kunci keberhasilan usaha.

\section{TINJAUAN PUSTAKA}

\section{Pengertian Kewirausahaan}

Banyak ahli mendefinisikan kewirausahaan dari beberapa sudut pandang yang berbeda. Entrepreneur adalah suatu kemampuan (ability) dalam berpikir kreatif dan berperilaku inovatif (Suryana, 2003) sebagai dasar mengelola sumber daya dalam rangka menghadapi tantangan zaman. Wirausahawan juga bisa diartikan orang yg memiliki kemampuan untuk menciptakan sesuatu yg baru, berbeda dari yg lain atau mampu menciptakan sesuatu yg berbeda dengan yang sudah ada sebelumnya (Drunker, 1994) serta mengubah sesuatu yang kurang produktif menjadi lebih produktif (widodo, 2005). Ini artinya bahwa ciri utama yang pertama seorang wirausahawan adalah kemampuannya mengembangkan kreatifitas dan inovasi dalam menjalankan usaha.

Dalam sudut pandang yang berbeda kewirausahaan dapat didefinisikan sebagai kemampuan menangkap peluang (Scarborough dan Zimmerer, 1993) dan mencocokkan peluang tersebut dengan sumber daya yang dimiliki, serta merealisasikan peluang tersebut dengan memanfaatkan dan mengoptimalkan sumber daya perusahaan, sehingga terwujud satu usaha yang nyata. Berdasar pengertian tersebut dapat dimaknai bahwa ciri wirausahawan yang kedua adalah kemampuan menangkap peluang dan mewujudkan peluang tersebut menjadi satu usaha baru.

(Scarborough dan Zimmerer, 1993; Steinhoff dan Burges, 1993) menjelaskan wirausaha sebagai kemampuan menghadapi resiko dan ketidakpastian dalam menciptakan usaha baru, mengorganisasikan, dan mengelola usaha tersebut. Kalau dua pandangan sebelumnya menyebutkan bahwa seorang wirausaha memiliki jiwa kreatif, inovatif, dan 
mampu menangkap peluang, maka pandangan yang ketiga ini menyebutkan bahwa seorang wirausaha pasti berani mengambil resiko. Keberanian mengambil resiko ini adalah upaya untuk mewujudkan peluang dengan memperhitungkan semua potensi dan sumber daya yang dimiliki.

Dari seluruh aspek dan sudut pandang para ahli, dapat disimpulkan bahwa pengertian kewirausahaan mengandung beberapa konsep seperti kemampuan untuk menciptakan sesuatu yang baru dan berbeda (kreativitas dan inovasi), mengorganisasi sumber daya, menangkap peluang, menanggung risiko, serta orientasi pada hasil.

\section{Karakter Kewirausahaan}

Karakteristik kewirausahaan meliputi karakteristik demografik, karakteristik individu, sifat personal, orientasi kewirausahaan, dan kesiapan kewirausahaan.

Karakteristik demografi seorang wirausaha biasanya dikaitkan dengan usia, jenis kelamin dan pengalaman dari pelaku usaha. Beberapa penelitian menjelaskan bahwa usia 25 sampai 45 tahun adalah usia yang menunjukkan seseorang paling aktif dalam berwirausaha (Miftakhuljannah, dkk, 2016). Begitu juga orang yang memiliki pengalaman sebelumnya dalam berwirausaha akan memiliki minat yang lebih besar dalam mengembangkan usaha dibanding orang yang belum pernah memiliki pengalaman wirausaha (Islam, Khan, Obaidulloh, 2011; Riyanti, 2003; Sapar, 2006; Dirlanudin, 2010; Kellermans, 2008).

Karakteristik individu meliputi faktor umur, pendidikan, pengetahuan manajerial, pengalaman industri, dan kemampuan sosial dari pelaku usaha pemilik/manajer. Pendidikan kewirausahaan menghasilkan individu yang memiliki usaha mandiri. Karakteristik personal terkait dengan karakteristik sifat, dan kepribadian kepribadian dari pelaku usaha. Termasuk dalam karakteristik personal adalah motivasi, percaya diri, keuletan, kepemimpinan, dan sifat lainnya yang terkait dengan pribadi dari pelaku usaha.

Orientasi kewirausahaan adalah dorongan pribadi yang terkait dengan usaha menjalankan sebuah usaha. Pelaku usaha yang memiliki orientasi kewirausahaan yang tinggi biasanya akan memiliki semangat yang tinggi dalam menangkap peluang usaha dan berusaha keras agar usahanya survive serta lebih maju dibandingkan dengan usaha pesaingnya. Mahrouq (2010), menjelaskan bahwa konsep orientasi berwirausaha berisi lima dimensi, yaitu otonomi, inovativitas, pengambilan resiko, proaktivitas, dan agresivitas kompetitif.

Kesiapan wirausaha adalah rasa percaya diri (self-efficacy) yang dimiliki oleh pelaku usaha dalam menjalankan usahanya. Self-efficacy atau rasa percaya diri adalah keyakinan seseorang akan kemampuan dirinya dalam menjalankan tugas atau menyelesaikan suatu pekerjaan. Orang biasanya bertindak berdasarkan pada keyakinannya akan kemampuan diri, dan bukan pada kemampuan itu sendiri. Sehingga keyakinan seseorang ini akan mempengaruhi pandangan dirinya terkait dengan apakah dia dapat menyelesaikan pekerjaan atau tidak, apakah tujuan akan tercapai atau tidak. Sehingga, seorang wirausaha dengan karakteristik percaya diri yang kuat akan akan meningkatkan keyakinan dirinya akan keberhasilan usaha yang sedang dijalankan.

Berbicara mengenai karakter kewirausahaan, maka banyak ahli yang menawarkan konsep karakter kewirausahaan. Beberapa karakteristik kewirausahaan yang dominan adalah pengalaman lamanya menjalankan usaha (Islam, Khan, Obaidulloh, 2010; Riyanti, 2003; Sapar, 2006; Dirlanudin, 2010; Kellermans, 2008), berani mengambil resiko (Scarborough dan Zimmerer, 1993; Mahrouq, 2010; Meredith, 1996; Soni, 2009; Puspitasari, 2013), inovasi (Thompson, 2005; Soni, 2009), rasa percaya diri (Scarborough dan Zimmerer, 
1993; Meredith, 1996; Bonet, Carlos dan Galindo, 2011), ketekunan dan kegigihan (Meredith, 1996; Dirlanudin, 2010; Puspitasari, 2013), kepemimpinan dalam menjalankan usaha (Meredith, 1996; Bonet, Carlos dan Galindo, 2011), serta motivasi wirausaha (Soni, 2009; Meredith, 1996; Bruning, 2011; Puspitasari,2013).

\section{Keberhasilan Usaha}

Menurut Noor (2007), keberhasilan usaha pada hakikatnya adalah keberhasilan dari bisnis dalam mencapai tujuannya. Keberhasilan usaha adalah tujuan utama dari sebuah perusahaan atau bisnis yang segala aktivitas didalamnya ditunjukan untuk mencapai suatu keberhasilan atau kesuksesan dalam pengertian umum, keberhasilan menunjukkan suatu keadaan yang lebih baik atau unggul dari pada masa sebelumnya.

Banyak ahli yang mendefinisikan indikator kesuksesan usaha dalam beberapa dimensi. Menurut Suyatno dan Chamdan (2010) berkaitan dengan faktor penentu keberhasilan usaha industri kecil ini, hasil penelitiannya menemukan bahwa keberhasilan usaha kecil ditandai oleh inovasi, serta perilaku mau mengambil resiko. Jumaidi (2012) dalam penelitiaannya meingidentifikasikan keberhasilan usaha dalam 4 indikator, tercapai tujuan usaha, produk diterima pasar, adanya laba produksi, dan kepuasan batin wirausaha. Sementara Islam, Khan dan Obaidullah (2011), menyatakan bahwa kesuksesan usaha dapat diukur dari tingkat survival, profit, hasil investasi, penjualan perusahaan, jumlah pekerja, kebahagiaan, reputasi dan sebagainya.

\section{METODE PENELITIAN}

\section{Pendekatan Penelitian}

Penelitian ini merupakan penelitian deskriptif kualitatif, yang bertujuan untuk memperoleh deskripsi data suatu variabel, dalam hal ini adalah variabel karakterisitk kewirausahaan dengan melalui pemaparan dan penjelasan ciri-ciri variabel yang bersangkutan.

\section{Responden}

Responden dalam penelitian ini adalah seluruh UMKM konveksi yang ada di dusun Sawahan dan Mlangi. Data secara resmi terkait dengan jumlah UMKM di dua dusun tersebut belum ada, hanya berdasarkan survey awal yang dilakukan peneliti, ada 57 UMKM konveksi yang saat ini berproduksi dengan rata-rata usia perusahaan di atas 5 tahun. Sampel diambil 6 UMKM dengan tehnik simple random sampling.

\section{Tehnik Pengumpulan Data}

Dalam penelitian ini, peneliti menggali karakteristik kewirausahaan yang dimiliki pelaku usaha di dusun Sawahan dan Mlangi, dengan menggunakan 6 (enam) indikator karakter, yaitu, karakter percaya diri, berani mengambil resiko, kepemimpinan, inovasi, motivasi usaha, dan terakhir adalah kegigihan/kesabaran dalam menjalankan usaha. Data diambil dengan menggunakan menyebarkan kuesioner dan wawancara mendalam terkait dengan jawaban dari kuesioner yang bersangkutan.

\section{Validasi Data}

Untuk mengetahui keabsahan data (apakah proses dan hasil penelitian dapat dipercaya atau tidak) maka peneliti menggunakan metode triangulasi, dengan cara memanfaatkan sesuatu yang lain diluar data untuk keperluan pengecekan atau sebagai pembanding terhadap data 
tersebut. Dan dalam penelitian ini peneliti menggunakan konsep teori sebagai pembanding dan komparasi data dari berbagai sumber.

\section{Tehnik Analisis Data}

Teknik analisis data yang digunakan adalah analisis kualitatif. Langkah-langkah dalam analisis data kualitatif melalui empat proses, yaitu mengumpulkan data, menyortir data yang tidak diperlukan, menyajikan dan menganalisis data, dan terakhir adalah menyimpulkan data.

\section{HASIL DAN PEMBAHASAN}

Penelitian ini menjelaskan temuan penelitian dalam tiga kerangka utama, profil umum UMKM, Karakteristik kewirausahaan yang dimiliki oleh UMKM , serta konsep keberhasilan usaha yang dipahami oleh UMKM di Sawahan dan Mlangi. Dalam penelitian ini ada 6 UMKM yang menjadi objek penelitian melalui penyebaran kuesioner dan wawancara mendalam. Karakteristik wirausahan yang diteliti terdiri dari 6 (enam) indikator yaitu, percaya diri, berani mengambil resiko, kepemimpinan, inovasi bisnis, motivasi usaha, dan kegigihan.

\section{Profil Umum}

Dusun Sawahan dan Mlangi memiliki 56 pelaku usaha konveksi. Berdasar pengamatan peneliti, ada tiga kategori UMKM di dusun Mlangi, pertama UKM menengah yang bergerak tidak hanya memproduksi pakaian jadi, tetapi juga menyediakan bahan mentah (kain) untuk UMKM skala kecil. Kedua, UMKM skala kecil yang memproduksi barang dari mulai bahan mentah (kain putihan) sampai barang pakaian jadi. Dan ketiga, UMKM skala kecil yang hanya memproduksi barang barang pakaian jadi dengan bahan yang dibeli dari supplier.

Produk yang dihasilkan adalah baju konveksi seperti daster, celana, rok, dan lain-lain produk konveksi lainnya. Terkait proses produksi, sebagian besar pelaku UMKM tidak memproduksi sendiri kain batiknya, akan tetapi mereka mengambil bahan yang sudah diproduksi dari pabrik, dan biasanya mereka mengambil pada distributor kain yang ada di Sawahan atau Mlangi. Distributornya sendiri mengambil kain dari pabrik Solo dan Pekalongan. Proses produksi yang dilakukan oleh pelaku usaha adalah proses pembuatan baju konveksi, dari mulai memotong, menjahit, memberi label dan mengepak dalam bungkus plastik. Akan tetapi, ada juga pelaku usaha yang melakukan proses produksi dari mulai proses membuat bahan kainnya sampai proses penjahitan selesai. Biasanya yang melakukan proses ini adalah pelaku usaha dengan produk jumputan atau lukis. Jenis produk yang diproduksi biasanya menyesuaikan dengan trend pasar yang sedang laku. Setiap UMKM mampu menyerap tenaga kerja rata-rata 7 - 15 orang tenaga kerja.

Untuk wilayah pemasaran, yang utama adalah kawasan wisata Malioboro dan pasar Beringharjo. Selain itu juga produk-produknya dipasarkan di daerah wisata di Jogja dan Jawa Tengah. Tehnik pemasaran yang digunakan adalah menjual secara langsung ke pedagang kaki lima atau toko-toko di lokasi wisata. Sistem pembayaran dengan cara kontan dan konsinyiasi. Selain menjual secara langsung, mereka juga membuka toko di rumah melayani pembeli dalam skala besar atau pembeli eceran. Dalam menentukan harga jual, pelaku UMKM di Sawahan dan Mlangi biasanya menetapkan harga jual berdasarkan harga jual yang berlaku di pasar. Rata-rata omset per bulan adalah 40 kodi (800 potong) untuk UMKM skala kecil, dan 100 kodi (2000 potong) untuk UMKM skala menengah. 
Yang menarik dari profil umum UMKM di dusun Sawahan dan Mlangi, hampir seluruh pelaku UMKM menguasai salah satu proses produksi, yaitu ketrampilan proses pemotongan kain, dan biasanya mereka melakukan proses tersebut sendiri, tanpa menggunakan pekerja. Selain keahlian dalam proses produksi, biasanya mereka juga ahli dalam pemasaran, dan seluruh pelaku UMKM di dusun Sawahan Mangi melakukan proses pemasarannya sendiri tanpa menggunakan tenaga kerja pemasaran. Dampaknya pemilik usaha yang merangkap sebagai pemasaran, maka mereka dengan cepat bisa merespon kebutuhan pasar. Terakhir, rata-rata pelaku UMKM di dusun Sawahan dan Mlangi melibatkan peran perempuan dalam hal ini istri dalam mengelola dan memajukan usaha. Bahkan beberapa UMKM. Inisiatif pendirian dan pengelolaan oleh istri.

\section{Analisis Data Karakter Kewirausahaan}

Berdasarkan hasil penelitian dapat dijelaskan bahwa, karakteristik kewirausahaan yang dimiliki oleh UMKM di Sawahan dan Mlangi memiliki karakteristik yang sama. Hanya kadar atau tingkat karakteristiknya berbeda-beda. Hal ini dapat dilihat dari hasil jawaban kuesioner atau wawancara mendalam. Karakteristik kewirausahaan yang dimiliki oleh UMKM berdasarkan hasil penelitian adalah percaya diri, berani mengambil resiko, kepemimpinan, inovasi bisnis, motivasi usaha, dan kegigihan.

Karakteristik pertama, percaya diri, dapat dijelaskan dalam gambaran keyakinan pelaku usaha di Sawahan dan Mlangi, dimana mereka memiliki rasa percaya diri dalam menjalankan usaha, dan sebagai salah satu karakter kewirausahaan yang menghantarkan bisnis mereka berhasil seperti saat ini. Dalam menjalankan usaha, modal utama mereka hanya keyakinan bahwa usaha mereka akan berjalan dengan lancar. Dalam diri mereka sudah terpatri keyakinan bahwa hanya Alloh sebagai tempat bergantung, sehingga mereka tidak pernah menggantungkan usaha mereka pada orang lain. Mereka yakin bahwa jika manusia berikhtiar dan berdoa dengan sungguh-sungguh pasti Alloh akan memberikan jalan kemudahan akan usaha yang mereka jalankan.

Karakter berani mengambil resiko tergambar dari keberanian mereka menjalani ritme kerja yang tidak sesuai ritme kerja orang biasa. Para pelaku bisnis konveksi yang berjualan di lokasi wisata di sekitar Malioboro Jogjakarta, biasanya mulai memasarkan produknya saat senja, selepas maghrib dan menunggu pembayaran sampai pedagang kaki lima yang menjadi pelanggannya tutup. Itu artinya mereka baru pulang ke rumah menjelang tengah malam. Bahkan saat musim liburan, mereka bisa pulang itu menjelang subuh, dengan membawa sisa dagangan dan uang hasil penjualan. Mereka tidak berfikir dengan kesehatan dan keamanan yang mengancam. Mereka tetap bertahan meski ritme pekerjaan melebihi pekerjaan orang normal.

Karakter kewirausahaan yang selanjutnya adalah kepemimpinan, yang dicerminkan dalam pernyataan yang terkait dengan kemampuan mengatur kerja team, kemampuan mengambil keputusan, kemampuan berkomunikasi, kemampuan memotivasi/mengatur diri sendiri. Pelaku usaha di dusun Sawahan dan Mlangi memiliki karakter kepemimpinan yang kuat. Salah satu bukti kuatnya karakter kepemimpinan tersebut adalah kemampuan mereka dalam berkomunikasi dan bernegosiasi, baik dengan pembeli maupun dengan distributor kain. Kemampuan berkomunikasi tersebut tergambar dari personal selling yang mereka lakukan di pasar, dengan ciri luwes, ramah, dan pandai merayu pembeli. Selain kepandaian berkomunikasi, gambaran kepemimpinan mereka tunjukkan dalam memotivasi diri dan keluarga untuk bersama-sama bekerja memajukan usaha. Dalam menjalankan usahanya, hampir seluruh keluarga terlibat dan memiliki peran dalam memajukan usaha, terutama 
pasangan suami atau istrinya. Bahkan tidak jarang kita temui, anak-anaknya pun ikut membantu sesuai dengan kadar kemampuan mereka, seperti melayani pelanggan yang datang, sekedar mengantarkan dagangan, atau ikut membantu produksi dalam hal ini pelabelan dan pengemasan. Akan tetapi berbeda dengan kondisi di atas adalah mereka belum mampu memotivasi pekerja untuk ikut berjuang memajukan usaha. Salah satu kelemahan usaha di daerah ini adalah tingkat loyalitas pekerja yang rendah, dan turn over yang tinggi. Ini bisa menjadi bukti ketidakmampuan pemilik usaha dalam memotivasi pekerja untuk loyal pada usaha mereka.

Inovasi adalah karakter kewirausahaan berikutnya yang di teliti. Sesuai dengan teori, inovasi dalam penelitian ini dibatasi hanya pada pengertian inovasi sebagai frekwensi pelaku usaha melakukan perubahan. Dari sini kemudian inovasi difokuskan pada aspek tingkat seorang pelaku usaha berfikir untuk melakukan perubahan dalam usaha, dan tingkat seringnya melakukan perubahan terhadap produk yang diproduksi. Terkait dengan karakter inovasi, responden melakukan inovasi produk hanya terkait dengan diversifikasi dan keragaman produk yang mereka buat, itupun bukan hasil ide mereka, akan tetapi dari permintaan pasar. Untuk inovasi proses produksi, pemasaran, pun organisasi, mereka juga belum melakukan inovasi dalam bidang terkait. Beberapa pelaku usaha sudah pernah mencoba membuat produk yang baru di luar trend pasar yang ada, dan selalu diterima pasar. Akan tetapi inovasi produk tersebut tidak ditindaklanjuti dengan serius. Dalam pemikiran mereka, jika dengan produk yang sudah ada saja usaha sudah jalan, mengapa harus bersusah payah menciptakan produk yang baru. Pengetahuan tentang pentingnya inovasi produk dan proses sudah banyak mereka dapatkan dari pelatihan-pelatihan yang mereka ikuti, akan tetapi semangat dan motivasi berinovasi yang masih belum terasah.

Karakterisitik motivasi usaha dalam penelitian ini menggunakan tiga indikator motivasi, yaitu motivasi memenuhi kebutuhan hidup, menjadi kaya, dan motivasi untuk menjadi orang sukses. Dari jawaban responden dapat dilihat bahwa seluruh responden setuju dengan motivasi memenuhi kebutuhan hidup, dan menjadi orang sukses. Akan tetapi mereka menjawab tidak setuju dengan motivasi menjadi kaya. Dari hasil wawancara mendalam tergali bahwa bagi warga Sawahan dan Mlangi, dalam jiwa mereka sudah tertanam nilai agama yang kuat bahwa konsep rejeki yang cukup dan barokah itu lebih penting daripada rejeki yang mengayakan. Sehingga pada saat mereka memulai usaha motivasi mereka bukan untuk menjadi kaya tetapi dalam rangka beribadah mencari rejeki yang halal, toyyib, dan berkah. Kalau kemudian dalam perjalanan usahanya menghasilkan nilai kekayaan yang berlebih, itu adalah rejeki yang disyukuri.

Karakter kewirausahaan yang terakhir yang diteliti adalah kegigihan dan kesabaran dalam menjalankan usaha. Indikator ini dicerminkan oleh pernyataan terkait dengan kegigihan, ketekunan, konsistensi (istiqomah), serta kesabaran dalam menjalankan usaha. Dari hasil penelitian terungkap bahwa karakter kegigihan dan kesabaran ini tidak terlepas dari nilai dasar agama yang mereka miliki yaitu perintah untuk tawakkal dalam segala ikhtiar. Yaitu sikap untuk selalu berikhtiar dan berdoa seoptimal mungkin, dan pasrah atas segala hasil yang diberikan oleh Alloh. Dari sini wajar apabila kemudian pelaku usaha di dusun Sawahan dan Mlangi sangat gigih dalam menjalankan usaha. Lebih lanjut berdasarkan wawancara, kegigihan tersebut dapat dilihat pada kinerja mereka sehari-hari. Hampir semua pelaku usaha di Sawahan dan Mlangi, memiliki ritme kerja di atas normal, yaitu dari pagi bangun tidur sampai malam menjelang tidur lagi. Hampir semua lini pekerjaan mereka berperan mengurus dan mengerjakan sendiri pekerjaannya, dari mulai mencari bahan, 
memproduksi, sampai memasarkan mereka lakukan sendiri. Semua upaya itu sebagai wujud kegigihan mereka dalam menjalankan usaha.

\section{Analisis Data Keberhasilan Usaha}

Keberhasilan usaha bisa diukur dari banyak sisi. Salah satu ukuran yang paling mudah adalah dilihat dari lamanya usaha. Jika dilihat dari lamanya usaha, maka UMKM di dusun Sawahan dan Mlangi dapat dikategorikan sebagai UMKM yang berhasil. Dari hasil penelitian diketahui bahwa seluruh UMKM di wilayah ini rata-rata sudah mendirikan usaha lebih dari 5 (lima) tahun untuk generasi terbaru, bahkan para perintisnya sudah memulai usaha ini dari awal tahun 1990-an dan masih bertahan sampai sekarang.

Terkait 6 (enam) UMKM yang menjadi responden, dapat diketahui bahwa sampai saat ini mereka sudah menjalankan usaha adalah antara 7 - 15 tahun. Ini berarti selama itu mereka sudah berhasil melalui tantangan, permasalahan-permasalahan, serta naik turunnya usaha yang mereka jalankan, dan masih tetap bertahan sampai sekarang, bahkan usahanya semakin meningkat dari waktu ke waktu. Peningkatan usaha tersebut ditandai dengan ukuran omset, jumlah tenaga kerja, asset yang semakin meningkat.

Keberhasilan usaha bagi UMKM di Sawahan dan Mlangi dimaknai dalam empat persepktif, pertama usaha berjalan dengan lancar, kedua rejeki yang cukup dan berkah, anak-anak yang sukses dalam sekolah dan mengaji, serta kebahagiaan saat menjalankan usaha. Mereka tidak menempatkan ukuran kaya sebagai ukuran finansial keberhasilan usaha, pun tidak juga keuntunganyang berlipat, akan tetapi secara finansial mereka menganggap kecukupan dan keberkahan sebagai ukuran utama. Cukup dan berkah adalah salah satu konsep rejeki dalam syareat islam. Bahwa orang mencari rejeki itu yang penting cukup untuk kebutuhan sehari-hari dan berkah dibagikan dan dimanfaatkan untuk umat.

\section{Pembahasan}

Sesuai dengan hasil penelitian dapat dijelaskan bahwa karakteristik kewirausahaan yang dimiliki oleh UMKM di dusun Sawahan dan Mlangi adalah karakter percaya diri, keberanian mengambil resiko, kepemimpinan, motivasi usaha, serta kegigihan dalam menjalankan usaha. Sesuai dengan teori, bahwa salah satu ciri utama seorang wirausaha adalah mampu menangkap peluang dan berani mengambil resiko. Salah satu karakter yang mendukung ciri tersebut adalah karakter percaya diri, motivasi, dan karakter berani mengambil resiko itu sendiri. Orang yang memiliki kepercayaan diri yang tinggi, dan dibarengi oleh motivasi yang kuat maka akan melahirkan keinginan yang kuat untuk mewujudkan semua rencana. Dalam proses mewujudkan rencana tentu saja harus dibarengi dengan keberanian memulai dan mengambil resiko atas apa yang dijalankan. Agar keputusan mengambil resiko tersebut dapat membuahkan hasil yang nyata, maka dibutuhkan manajemen dan pengelolaan yang baik. Di sinilah kemudian peran karakter kepemimpinan, dan karakter kegigihan akan memberikan kontribusi dalam kesuksesan usaha. Terkadang orang yang memiliki keberanian mengambil resiko, hanya asal terbawa hawa nafsu dalam keputusannya, oleh karena itu, agar tidak menimbukan kerugian, maka faktor kepemimpinan yang baik, manajemen yang baik akan menghantarkan pada tingkat pengelolaan yang baik pula, sehingga resiko kerugian bisa dihindari.

Karakter inovasi/kreatif dalam penelitian ini ternyata tidak terbukti memberikan kontribusi terhadap keberhasilan usaha UMKM di dusun Sawahan dan Mlangi. Bagi pelaku 
usaha di wilayah tersebut, proses inovasi belum mereka lakukan secara intens. Ini bisa dijelaskan dari dua sudut pandang, pertama pemahaman dan pengetahuan mereka tentang inovasi masih terbatas pada inovasi produk, sementara produk yang mereka produksi selama ini hanya berdasarkan trend dan permintaan pasar. Kedua, dilihat dari motivasi berusaha serta cara mereka memaknai keberhasilan usaha, membuat mereka cepat puas dengan pencapaian saat ini. Bagi mereka untuk apa mereka bersusah payah memikirkan dan membuat produk baru, kalau produk yang sudah ada saja sudah mampu membuat mereka berhasil masuk dan bertahan dalam persaingan pasar.

Dalam wawancara mendalam, terungkap bahwa tingkat religiusitas, menjadi salah satu variabel yang mempengaruhi keberhasilan usaha. Meskipun variable ini tidak ikut diteliti, akan tetapi hasil wawancara menunjukkan bahwa karakter wirausaha yang dimiliki oleh UMKM banyak dibangun oleh pemahaman agama dan tingkat religiusitas mereka dalam menjalankan agama. Hal ini sejalan dengan penelitian yang dilakukan oleh Mustikowati dan Wilujeng (2016), dimana mereka meneliti tentang tingkat religiusitas dan kewirausahaan dalam mencapai kinerja usaha UMKM di Malang. Hasil penelitian mereka menyebutkan bahwa tingkat religiusitas memiliki pengaruh positif terhadap pencapaian kinerja UMKM.

Untuk variabel keberhasilan usaha, dapat diukur dari lamanya mereka menjalankan usaha rata-rata sudah lebih dari 7 (tujuh) tahun, ini berarti cara mereka memaknai keberhasilan usaha ditinjau dari sisi usaha berjalan lancar dari waktu ke waktu sudah membuahkan hasil. Dan dari perjalanan usaha mereka, terindentifikasi cara UMKM memaknai keberhasilan usaha ternyata bukan sekedar lamanya usaha saja, akan tetapi juga kecukupan dan berkah secara finansial, anak-anak yang sukses sekolah dan mengaji, serta kebahagiaan menjalani usaha. Ini menunjukkan bahwa mereka bisa memaknai usaha tidak sekedar untuk pemenuhan kebutuhan dasar saja, akan tetapi lebih dari itu adalah proses membangun kebahagiaan hidup serta kemanfaatan bagi diri, keluarga, dan masyarakat.

\section{KESIMPULANDAN IMPLIKASI}

Penelitian ini mengkaji tentang karakteris kewirausahaan dan dan keberhasilan usaha pada UMKM di dusun Sawahan dan Mlangi Nogotirto Gamping Sleman Yogyakarta. Tujuan dari penelitian adalah untuk mengidentifikasikan profil usaha UMKM, mengkaji karakter kewirausahaan yang dimiliki, serta mengkaji makna keberhasilan usaha menurut UMKM di di dusun Sawahan dan Mlangi.

Profile usaha UMKM di dusun Sawahan dan Mlangi adalah masuk dalam usaha kecil dan menengah, dengan omset penjualan per bulan rata-rata 40 kodi untuk usaha kecil, dan 100 kodi untuk usaha menengah. Produk yang dihasilkan adalah produk-produk pakaian konveksi seperti daster, celana, rok, hem, stelan anak, dompet, jilbab, dan lain-lain, dengan penyerapan tenaga kerja antara 7 - 15 TK per UMKM.

Karakter kewirausahaan yang melekat dan berhubungan dengan keberhasilan usaha adalah karakter percaya diri, berani mengambil resiko, kepemimpinan, motivasi usaha, dan kegigihan serta kesabaran dalam menjalankan usaha.

Keberhasilan usaha dapat diukur dari lamanya mereka menjalankan usaha, dimana paling muda menjalankan usaha dari 7 (tujuh) tahun yang lalu, dengan pertumbuhan usaha yang semakin meningkat dari tahun ke tahun. Selain itu keberhasilan usaha juga dimaknai dalam aspek lain, seperti kecukupan dan keberkahan secara finansial, anak-anak yang sukses dalam studi dan mengaji, serta kebahagiaan dalam menjalankan usaha. 
Implikasi dari penelitian ini. Bisa digunakan sebagai dasar bagi UMKM untuk merumuskan strategi usaha ke depan, terutama dalam pengembangan SDM, pola kepemimpinan, dan strategi inovasi untuk memenangkan persaingan. Selain itu dengan adanya profil usaha bisa dijadikan sebagai patokan untuk memetakan kekuatan, kelemahan, peluang, serta ancaman yang dihadapi pelaku usaha. Implikasi keilmuan, penelitian ke depan bisa difokuskan pada upaya membangun wirausaha syariah pada UMKM di dusun Sawahan dan Mlangi dengan memasukkan variabel karakter wirausaha, religiusitas dan inovasi, serta keberhasilan usaha itu sendiri sebagai bangunan dalam membentuk komunitas wirausaha syariah.

\section{DAFTAR PUSTAKA}

Bonet, P.F.; Carlos R.A.; and Galindo M.A., 2011,Entrepreneurial Success and Human Resources, International Journal OfManpower, Vol.31, No.1, 68-80.

Casson M, Yeung B, Basu A, Wadeson N, 2006, The Oxford Handbook of Entrepreneurship, Oxford University Press Inc, New York

Chamduang, Daowieng, Jorajit, 2012, Effect of Entrepreneurial Characteristics on the Business Success of Small and Medium Enterprises in Songkhla, Proceedings-Sufficiency Economy and CommunityEnterprise-001 4th InternationalConference on Humanities and SocialSciences April 21st, Faculty of LiberalArts, Prince of Songkla University

Dinas Koperasi dan UKM Kabupaten Sleman, 2017, www.dinkopukm.slemankab.go.id

Dirlanudin. 2010. Perilaku Wirausaha dan Keberdayaan Pengusaha Kecil Industri Agro: Kasus di Kabupaten Serang Provinsi Banten [Disertasi]. Bogor : Institut Pertanian Bogor.

Drunker, P.F., 1994, Innovation and Entrepreneurship, New York, Harpercollins Publisher

Indiarti, Nurul. dan Maria Langenberg, 2004, Factors Affecting Business Success among SMEs: Empirical Evidences from Indonesia, Journalof Asia Entrepreneurship andSustainability, Volume III

Islam, Khan dan Obaidullah, 2011, Effect of Entrepreneur and Firm Characteristics on the Business Success of Small and Medium Enterprises (SMEs) in Bangladesh, International Journal of Business andManagement Vol. 6, No. 3, March edition

Islam, Keawchana dan Yusuf (2011), Factors Affecting Business Success of Small \& Medium Enterprises (SMEs) in Thailand. Journal Asian Social ScienceVol. 7, No. 5, May edition

Jumaidi Heri, 2012, Hubungan Karakteristik Wirausaha Terhadap Keberhasilan Usaha (Studi Kasus Pada Perusahaan Kecil Di Pekalongan), Jurnal Manajerial,Vol.11, No 21

Kellermanns FW, Floyd SW. 2008.An Exploratory Study of Family Member Characteristics and Involvement:Effects on Entrepreneurial Behavior in the Family Firm. In: Eds S.Family Business Review 2008.

Kementrian Koperasi dan UKM, 2012, www.depkop.go.id 
Meredith G.G., Nelson R.E., dan Nick P.A.. 1996. Kewirausahaan Teori dan Praktek.Dialih bahasakan oleh Andre Asparsayogi. Jakarta: Pustaka Binaman Pressindo

Miftakhuljannah, O.; Priatna, B.W.; Suharto, 2016, Karakter Wanita Wirausaha Pada Industri Kecil Kerupuk Kemplang Di Kabupaten Ogan Hilir, Jurnal Agribisnis Indonesia, Vol 4 No 2, halaman 123-136

Mutis, Thoby. 1995, Pembangunan Koperasi, Jakarta: Yayasan Bina Bakti Utama.

Mustikowati I.R., Wilujeng S, 2016, Religiusitas dan Kewirausahaan : Faktor Kritis dalam Mencapai Kinerja Bisnis pada UMKM di Kota Malang, Jurnal Studi Manajemen dan Bisnis, Vol 3 : No.2

Noor, Henry Fauzan, 2007. Ekonomi Manajerial. PT Raja Grafindo Persada, Jakarta

Puspitasari. 2013. Pengaruh Perilaku Kewirausahaan Petani Anggrek Terhadap Kinerja Usaha: Kasus di Kecamatan Gunung Sindur dan Parung, Kabupaten Bogor, dan Kecamatan Serpong, Kota Tangerang Selatan [Tesis]. Bogor: Institut Pertanian Bogor.

Riyanti BP .2003. Kewirausahaan Dari Sudut Pandang Psikologi Kepribadian. Jakarta : PT.Grasindo.

Sapar. 2006. Faktor-Faktor yang Berhubungan Dengan Perilaku Kewirausahaan Pedagang Kaki Lima [Tesis]. Bogor: Institut Pertanian Bogor.

Scarborough, Norman M, Thomas W. Zimmerer. 1993. Effective Small Business Management 4th ed. New York: Mac---Millan Publishing Company

Sugiono, 2007, Memahami Penelitian Kuantitatif, Alfabeta, Bandung

Sumarsono, Sony, 2010, Kewirausahaan, Graha Ilmu, Yogyakarta

Suryana. (2001), Kewirausahaan, Salemba Empat, Jakarta

Suryana, 2009, KewirausahaanPedoman Praktis : Kiat dan Proses Menuju Sukses, Penerbit Salemba Empat, Jakarta

Suyatno Purnam, Chamdan, 2010, Motivasi dan Kemampuan Usaha Industri Kecil Sepatu di Jawa Timur, Jurnal Manajemen dan Kewirausahaan, pp 177-184

Steinhoff D, Burgess, J.F, 199, Small Business Management Fundamentals 6th ed. New York: McGraw hill Inc

Thompson, V. A, 2005, Bureaucracy and Innovation, AdministrativeScience Quarterly 10, pp. 120.

Trevelyan, Rose, 2011, Self-Regulation and Effort In Entrepreneurial Task, International Journal OfEntrepreneurial Behaviour AndResearch, Vol.17, No.1, 39-63. 
Widodo Muladi, 2011, Pembelajaran Kewirausahaan dan Minat Wirausaha Lulusan SMK, Eksplanasi Volume 6 Nomor 2 Edisi September

Wijaya, 2008, Kajian Model Empiris Perilaku Berwirausaha UKM DIY dan Jawa Tengah, Jurnal Manajemen dan Kewirausahaan, September, Vol. 10 no. 2, hal 93-103

Widodo, Winarso Drajad, 2005, Jendela Cakrawala Kewirausahaan, IPB Press

Zhang, David Di and Bruning, Edward, 2011, Personal Characteristics And Strategic Orientation: Entrepreneurs In Canadian Manufacturing Companies, International Journal ofEntrepreneurial Behaviour andResearch, Vol.17, No.1, 82-103. 